\title{
Abiotic Changes Within a Reservoir After a Complete Drawdown: A Case Study of Lake Griffy
}

\author{
Gregory P. Welage, School of Public and Environmental Affairs, Indiana University Bloomington
}

\section{ABSTRACT}

\begin{abstract}
A quatic ecosystems are created and dictated by their physical and chemical environment; when catastrophic events cause an A ecosystem shift, such as the draining and refilling of a reservoir, the composition and quality of the ecosystem state can change based on the new physical and chemical environment. This research project examines the physical and chemical limnological changes in Griffy Lake, Bloomington, IN, after the complete drawdown of water for the purpose of dam reconstruction. After two years of sediment oxidation and terrestrial plant growth, the reservoir naturally refilled. The study summarizes recovery results from data collected on a monthly basis. The results focus on the variables of temperature, dissolved oxygen, alkalinity, $\mathrm{pH}$, specific conductance, and nutrient concentrations. After analysis of the data, this project will allow for better understanding of the effects of complete drawdowns on abiotic variables. The work presented is part of a larger project that will examine how aquatic ecosystems recover and ecosystem states may shift within reservoirs after complete drawdowns. With more than 75,000 dams across the United States, many of which are approaching the end of their life spans, in the near future it is important to understand how such events affect the quality of the water, in addition to aquatic ecosystems.
\end{abstract}

\section{KEYWORDS: limnology, complete drawdown, abiotic variables, reservoir}

\section{INTRODUCTION}

As the human population continues to increase and the economy attempts to keep up, the demand for freshwater is at an all-time high. In addition to the basic need of humans to consume water daily, large amounts of freshwater are required for everyday agricultural and industrial practices. Although the Earth's surface is covered by about $71 \%$ water, approximately $0.3 \%$ of that volume of water is in the useable form of freshwater lakes, rivers, and ground water (Wetzl, 2001). As other factors such as pollution and climate change also add to the stresses placed on freshwater ecosystems, the sustainable management of these water resources is necessary for the survival of both humans and aquatic ecosystems. Specifically, the management of freshwater lakes (and reservoirs) is important because many of them serve as resources for a myriad of purposes. Freshwater lakes are used for drinking water sources, recreational areas, power generation, and flood protection. As the dambuilding era has slowed and the creation of reservoirs is being reconsidered due to its negative ecological impacts, it is important to responsibly manage these functional reservoirs. It is critical to understand the functional ecosystem processes to effectively manage a reservoir. Understanding ecosystem processes such as biogeochemical cycles is an integral part in the management of lakes and reservoirs (Holdren, Jones, \& Taggart, 2001).

This study looks at the long-term effects of a twoyear, complete drawdown on abiotic variables within a reservoir. Biogeochemical cycles, such as the carbon, nitrogen, and phosphorous cycles, are important to understand for managing a lake because they dictate the primary productivity as well as the water quality. Quickly colonizing terrestrial species of plants and the oxidation of lake sediment have the potential to cause a large release of nutrients after the lake has refilled. This study analyzes the monthly and seasonal trends for abiotic variables in addition to comparing sampled data to historical data from past Indiana Clean Lakes Program sampling events prior to the complete drawdown.

\section{BACK GROUND}

Griffy Lake is a eutrophic reservoir located north of the Indiana University campus in Bloomington, Indiana. Griffy Lake was created after the construction of the Griffy dam in 1924 by the Bloomington Water Company to supplement drinking water to the city of 
NATURALSCIENCES

Bloomington (Peel, 2008). The water treatment plant was decommissioned in 1995, but Griffy Lake remains as a backup water supply. Griffy Lake is owned by the City of Bloomington Utilities Service Board, but through an agreement between the Utilities Board and the Board of Parks \& Rec (Parks \& Rec), recreational activities are managed and developed by Parks \& Rec (Peel, 2008).

Griffy Lake has a surface area of approximately 485,000 $\mathrm{m}^{2}$ (119 acres) and holds a capacity of approximately $2,300,000 \mathrm{~m}^{3}$ (1865 acre-feet) with a maximum depth of 10 meters. The watershed that drains into Griffy Lake is approximately $20,800,000 \mathrm{~m}^{2}$ (5139 acres) in area and includes University Lake. The watershed contains two nature preserves. The 1,180 acre Griffy Lake Nature Preserve is owned by the City of Bloomington Utilities Service Board, but recreational activities are developed and managed by Parks \& Rec. Indiana University owns 1,100 acres within the Griffy watershed known as the Indiana University Research and Teaching Preserve (IURTP) that is used for research and educational purposes (Peel, 2008).

\section{METHODS}

\section{Field Procedures}

Field procedures were followed as outlined in IDEM's Indiana Clean Lakes Program Manual and Standard Methods for the Examination of Water and Wastewater, 21 st Edition (APHA, 2005). Water samples were collected from the epilimnion (measured from the surface to 2 meters below the surface) and from the hypolimnion ( 1 meter above the bottom of the lake). A 2-meter long integrated sampler was used to capture an epilimnetic whole-water sample. Water samples were collected monthly, with supplemental bi-monthly samples collected by Parks \& Rec employees. Sample bottles for Ammonia and Nitrate $\left(\mathrm{NH}_{4}^{+}-\mathrm{N} / \mathrm{NO}_{3}^{-}-\mathrm{N}\right)$, Total Phosphorus (TP), and Total Kjeldahl Nitrogen (TKN) were prepared with $0.15 \mathrm{~mL} \mathrm{H}_{2} \mathrm{SO}_{4}$ for sample preservation; acid-washed glass bottles were used for TP and Soluble Reactive Phosphorus (SRP) samples; plastic sample bottles were used for $\mathrm{NH}_{4}{ }^{+}-\mathrm{N} / \mathrm{NO}_{3}{ }^{-} \mathrm{N}$, Alkalinity, and TKN. In situ measurements included Secchi disk transparency as well as temperature and dissolved oxygen profiles at each meter using a Hydrolab Datasonde.

\section{Laboratory Procedures}

Laboratory procedures were followed as outlined in Standard Methods for the Examination of Water and Wastewater, $21^{\text {st }}$ Edition (Rice, Baird, Eaton, \& Clesceri, 2005). SRP is analyzed using the ascorbic acid method and measured colorimetrically on a spectrophotometer (APHA, et al. 2005). TP samples are digested prior to analysis with hot acid to transform particulate phosphorus compounds into a dissolved form. After $\mathrm{pH}$ adjustment, the TP samples are analyzed with the same methods as SRP. $\mathrm{NH}_{4}{ }^{+}-\mathrm{N} / \mathrm{NO}_{3}{ }^{-} \mathrm{N}$ samples are filtered with a 0.45 micron membrane filter and a vacuum pump. An Aplkem Flow Solution Model 3570 autoanalyzer (OI Analytical, 2000) is used analyze the nutrient concentration in the samples. TKN samples are first digested in hot acid in addition to being filtered with syringe filters prior to analysis with the autoanalyzer.

\section{RESULTS}

\section{Temperature}

Temperature profiles from March to October depict the formation and breakdown of thermal stratification within the water column (Figure 1). The thermocline began to form in late May between the 1 and 7 meter depth with an average slope $2.1^{\circ} \mathrm{C} / \mathrm{m}$. The thermocline continued to develop until it reached its maximum slope of $4.9^{\circ} \mathrm{C} / \mathrm{m}$ between the 3 and 4 meter depth in July and the metalimnion was defined by an average slope of $3.3^{\circ} \mathrm{C} / \mathrm{m}$ between the 3 and 8 meter depths. Griffy Lake remained strongly stratified through July into August. August had a thermocline slope of $4.3^{\circ} \mathrm{C} / \mathrm{m}$ between the 5 and 6 meter depth and an average slope of $2.8^{\circ} \mathrm{C} / \mathrm{m}$ in the metalimnion between the 3 and 8 meter depths. The maximum surface temperature was $25.9^{\circ} \mathrm{C}$ in June and the minimum surface temperature was $5.1^{\circ} \mathrm{C}$ recorded in March.

\section{Dissolved Oxygen}

Oxygen profiles generally mirror temperature profiles in eutrophic lakes and reservoirs during thermal stratification. The oxygen profile of Griffy Lake from March to October is characterized as a clinograde 
curve. The maximum oxygen concentration of 10.8 $\mathrm{mg} / \mathrm{L}$ was measured in April at the 1 meter depth, while the minimum oxygen concentration in the epilimnion was $5.5 \mathrm{mg} / \mathrm{L}$ at the 2 meter depth in June. For each sampling event from March to October, concentrations were less than $1 \mathrm{mg} / \mathrm{L}$ in the hypolimnion at the 9 meter depth (Figure 2).

\section{Phosphorus}

Phosphorus is often the limiting nutrient in freshwater lakes; therefore, it is readily used by primary producers and is often measured at its detection limit in the epilimnion. Samples from Parks \& Rec sampling events were used for the month of July due to sampling and/or analysis error. Epilimnetic SRP concentrations were at the detection limit of $0.010 \mathrm{mg} / \mathrm{L}$ for all sampling events. Hypolimnetic SRP samples were measured at the detection limit for the spring (March, April, \& May) sampling events. The maximum epilimnetic TP concentration was collected in August and the maximum hypolimnetic concentrations for SRP and TP were collected in October (Table 1). As the metalimnion developed and became thermally stratified, hypolimnetic phosphorus concentration remained below $0.1 \mathrm{mg} / \mathrm{L}$ until August when SRP and TP hypolimnion concentrations increased approximately three-fold and seven-fold, respectively. SRP and TP hypolimnion concentrations continued to increase during the months of September and October.

\section{Nitrogen}

Nitrogen concentration trends varied between the oxidized $\left(\mathrm{NO}_{3}^{-}-\mathrm{N}\right)$ and reduced forms $\left(\mathrm{NH}_{4}{ }^{+} \mathrm{N}\right.$ \& $\mathrm{TKN}$ ) from March to October. The maximum $\mathrm{NO}_{3}$ -N concentrations in epilimnion and hypolimnion were collected in March (Table 2). The spring months had the highest epilimnetic and hypolimnetic $\mathrm{NO}_{3}^{-}-\mathrm{N}$ concentrations with an average of 0.409 and $0.227 \mathrm{mg} / \mathrm{L}$, respectively. The average $\mathrm{NO}_{3}{ }^{-} \mathrm{N}$ concentrations for the summer (June, July, \& August) and fall (September \& October) months were $0.121 \mathrm{mg} / \mathrm{L}$ for the epilimnion and $0.037 \mathrm{mg} / \mathrm{L}$ for the hypolimnion. Samples from Parks \& Rec sampling events were used for the months of June and July due to sampling and/or analysis error. Epilimnetic $\mathrm{NH}_{4}^{+}-\mathrm{N}$ and TKN concentrations remained relatively constant with an average concentration of 0.088 and $0.337 \mathrm{mg} / \mathrm{L}$, respectively. Maximum $\mathrm{NH}_{4}^{+}{ }^{-} \mathrm{N}$ and TKN concentration from the hypolimnion were collected in October (Table 2). Average $\mathrm{NH}_{4}^{+}-\mathrm{N}$ hypolimnetic concentration for spring and summer months was $0.575 \mathrm{mg} / \mathrm{L}$, while fall months had an average hypolimnetic concentration of $1.677 \mathrm{mg} / \mathrm{L}$. TKN concentration trends matched $\mathrm{NH}_{4}{ }^{+}-\mathrm{N}$ because $\mathrm{NH}_{4}^{+}-\mathrm{N}$ is a component within the TKN variable. The average TKN hypolimnetic concentration for spring and summer months was $0.900 \mathrm{mg} / \mathrm{L}$, while the average TKN concentration for fall months was $2.486 \mathrm{mg} / \mathrm{L}$.

\section{Alkalinity, pH, and Specific Conductance}

The $\mathrm{pH}$ of Griffy Lake varied between 6.8 and 8.1 in the epilimnion and 7.0 and 7.7 in the hypolimnion between March and October (Table 3). The greatest difference between epilimnetic and hypolimnetic $\mathrm{pH}$ values were during the summer months. Epilimnetic alkalinity concentrations remained relatively constant from March to October; measurements in the spring months had the lowest concentrations with an average of $80.3 \mathrm{mg} / \mathrm{L}$ (as $\mathrm{CaCO}_{3}$ ).

Epilimnetic alkalinity values increased to its maximum concentration of $152 \mathrm{mg} / \mathrm{L}$ (as $\mathrm{CaCO}_{3}$ ) in June and the average concentration for the summer and fall months was $134 \mathrm{mg} / \mathrm{L}$ (as $\mathrm{CaCO}_{3}$ ). Hypolimnetic alkalinity concentrations also had the lowest values in the spring months with an average of $106 \mathrm{mg} / \mathrm{L}$ (as $\mathrm{CaCO}_{3}$ ).

Alkalinity concentrations in the hypolimnion increased during the summer and reached its maximum in August with a concentration of $351 \mathrm{mg} / \mathrm{L}$ (as $\mathrm{CaCO}_{3}$ ). The fall samples had an average concentration of 262 $\mathrm{mg} / \mathrm{L}$. On average, hypolimnetic alkalinity values increased approximately $194 \mathrm{mg} / \mathrm{L} / \mathrm{month}$ (as $\mathrm{CaCO}_{3}$ ).

Epilimnetic and hypolimnetic specific conductance values had minimums in March with values of 241 and $481 \mu \mathrm{S} / \mathrm{cm}$, respectively. The specific conductance increased each month with an average slope of $26 \mu \mathrm{S} /$ $\mathrm{cm} / \mathrm{month}$ for the epilimnion and $185 \mu \mathrm{S} / \mathrm{cm} / \mathrm{month}$ for the hypolimnion. Maximum values were collected in October with an epilimnetic specific conductance of $422 \mu \mathrm{S} / \mathrm{cm}$ and a hypolimnetic specific conductance of $1592 \mu \mathrm{S} / \mathrm{cm}$. 
NATURALSCIENCES

Water clarity, measured as Secchi depth, varied between 0.45 meters and 6.2 meters. The greatest water clarity occurred during the July sampling event. Water clarity generally increased from March to July then gradually decreased from July to October (Figure 11).

\section{METHODS}

Abiotic changes naturally occur in lakes and reservoirs at different temporal and spatial scales. Important temporal scales include diel and seasonal cycles, which are determined by geographic factors like climate, location, and elevation. Furthermore, the shape of the basin of each lake determines the lake hydrology, watershed inputs, lake productivity, and biogeochemical cycles (Wetzl, 2001). Additionally, the basin morphology of each lake determines the residence time and surface area to volume ratio between the water column and the sediment which influence how abiotic factors within a reservoir will change.

The following analysis summarizes the abiotic changes within Griffy Lake by comparing pre- and postdrawdown sampling events in July and August. The historical data collected for Griffy Lake was obtained from the Clean Lakes Program database for sampling events in July 1990, 1997, and 2009 and August 2001 and 2011. Previous studies have determined that the oxidation and drying of sediments resulted in increased internal phosphorus loading after the sediments were re-inundated on a short-term scale (DeGroot \& Van Wijck, 1993; Klotz \& Linn, 2001; James, Barko, Eakin, \& Helsel, 2001). Since pre-drawdown sampling events were conducted in the months of July and August, postdrawdown data from July and August were averaged to compare lake conditions during the same time of the year.

\section{Temperature and Dissolved Oxygen}

During the sample period from March to October, the development and breakdown of thermal stratification were captured (Figure 1). Water temperature is a critical variable to measure because the solubility of a compound, such as dissolved oxygen and carbon dioxide, varies with temperature. Additionally, when a thermocline, or the plane of maximum rate of decrease of temperature, develops or the plane of maximum rate of decrease of temperature in the metalimnion, it becomes a physical and chemical barrier that opposes the movement of nutrients from the hypolimnion to the epilimnion via mixing or diffusion (Wetzl, 2001). The average difference between the historical temperature profiles and data collected in July and August 2014 was $2.3^{\circ} \mathrm{C}$ and the average difference between the curves is approximately $1.3 \mathrm{mg} / \mathrm{L}$ (Figure 12).

Dissolved oxygen is not the only factor that determines the distribution of biota; abiotic variables such as the different forms of nitrogen and phosphorus in the epilimnion and hypolimnion affect this distribution as well. As the thermocline strengthens during the summer, phosphorus is consumed by primary producers in the epilimnion and cannot be replenished via mixing from the hypolimnion due to the thermocline. Additionally, decomposers create a biochemical oxygen demand (BOD) in the hypolimnion due to their need to consume oxygen for metabolism that cannot be replaced due to the thermocline, which creates an anoxic environment. As the BOD reaches its maximum, the clinograde oxygen curve closely mirrors the temperature curve. Because the oxygen distribution becomes closely coupled to the thermocline, this area of water becomes a reduction and oxidation (redox) plane that separates the distribution of nutrients into their reduced and oxidized forms, such as the distribution of $\mathrm{NH}_{4}^{+}{ }^{+} \mathrm{N}$ and $\mathrm{NO}_{3}^{-}-\mathrm{N}$.

\section{Nitrogen}

Due to the constant mixing and circulation of the epilimnion, elemental nitrogen from the atmosphere (approximately $78 \% \mathrm{~N}_{2}$ ) is able to freely dissolve into the water. Primary producers are able to uptake the elemental nitrogen and convert into a usable form for metabolic processes. Because nitrogen is able to dissolve freely into the epilimnion, nitrogen is rarely a limiting nutrient in freshwater lakes and reservoirs. However, periods of rapid primary production can lead to nitrogen being a limiting nutrient. Nitrate, the oxidized form of nitrogen, was collected in greater concentrations for both historical and July-August 2014 sampling events in the epilimnion than the hypolimnion. This distribution of nitrate is due to the availability of dissolved oxygen in the epilimnion in addition to the lack of dissolved 
oxygen in the hypolimnion from the thermocline and BOD. Conversely, the hypolimnetic $\mathrm{NH}_{4}{ }^{+}-\mathrm{N}$ and TKN concentrations for both the historical and July-August data are higher in the hypolimnion because they are the reduced form of nitrogen, which forms readily in anoxic environments. The mean epilimnetic and hypolimnetic July-August $2014 \mathrm{NO}_{3}^{-}-\mathrm{N}$ concentrations are lower than the historical data, while the July-August 2014 $\mathrm{NH}_{4}{ }^{+}-\mathrm{N}$ and TKN concentrations are higher (Table 4). This increase in post-drawdown hypolimnetic $\mathrm{NH}_{4}{ }^{+}-\mathrm{N}$ and TKN concentrations may be due to the increased organic material present from terrestrial plant growth during the drawdown.

\section{Phosphorus}

Unlike nitrogen, phosphorus lacks a common, stable gaseous form, which results in phosphorus often being the limiting nutrient in most freshwater lakes and reservoirs across the United States. As the limiting nutrient, it is directly related to primary production within a lake. Due to the high demand of phosphorus by primary producers, implications for water quality problems include algae blooms, which are often fueled by large inputs of anthropogenically-sourced phosphorus. Additionally, large amounts of phosphorus can be stored in the sediment, which can be orders of magnitude larger than the phosphorus concentration in the water column (Wetzl, 2001).

Although there are many different forms of phosphorus, the dissolved inorganic form, known as SRP or orthophosphate, is the only form that primary producers can uptake and use for metabolic processes. Due to the constant demand of SRP by primary producers, it is almost instantaneously taken up when it is available in the epilimnion and therefore is often measured at its detection limit. As the thermocline strengthens during the summer, it prevents SRP and TP in the hypolimnion from mixing in the epilimnion, this further reduces phosphorus availability.

As the clinograde oxygen curve strengthens and creates an anoxic hypolimnion, it allows for the potential for phosphorus release from the sediments. In oxic conditions, the exchange of inorganic phosphorus between the sediment-water interface largely favors sediment absorption; however, when the environment is anoxic, the exchange is determined by the redox conditions at the sediment-water boundary (Frevert $1979 \mathrm{~b}$ in Wetzl, 2001). The release of phosphorus from the sediments has been determined as largely due to the reduction of $\mathrm{Fe}$ (III) to $\mathrm{Fe}$ (II) with subsequent release of orthophosphate (Wetzl, 2001). Several abiotic and biotic factors can influence the redox conditions at the sediment-water boundary, such as the type of sediment and its ability to retain phosphorus, the physical and chemical characteristics of the water above the sediment-water interface, as well as biota that may alter the transport of phosphorus across the sediment-water interface (Wetzl, 2001).

The expected SRP and TP distribution between the epilimnion and hypolimnion for a eutrophic reservoir undergoing thermal stratification in the summer was seen in both datasets; SRP and TP concentrations were measured at or near the detection limit in the epilimnion, while the hypolimnion contained concentrations above the detection limit (Table 4). The July-August 2014 hypolimnetic SRP and TP concentrations were nearly nine and three times larger, respectively, than the historical concentration.

\section{Alkalinity, pH, specific conductance, and Secchi depth}

The $\mathrm{pH}$ of most temperate, freshwater lakes ranges from 6 to 9 (Wetzl, 2001). Griffy's epilimnion and hypolimnion, both historical and July-August 2014 samples, were within this normal range. The epilimnion for the historical and July-August 2014 samples had an average $\mathrm{pH}$ of 8.2 , which was more basic than their respective hypolimnetic values. The July-August 2014 hypolimnetic samples had an average $\mathrm{pH}$ slightly more acidic than the historical hypolimnion vales with values of 7.4 and 7.6, respectively.

Alkalinity is defined as the buffering capacity or acid neutralizing capacity of the lake (Wetzl 2001). This measurement defines how much acid the lake can absorb without changing its $\mathrm{pH}$. The July-August 2014 minimum, maximum, and mean alkalinity values were greater than historical values in both the epilimnion and hypolimnion. The mean alkalinity value for the July-August 2014 hypolimnion was nearly double the concentration of the historical mean hypolimnetic value (Table 5). This increase in alkalinity indicates that Griffy 
Lake is more buffered to acid than previously before the drawdown.

Specific conductance is a measurement of dissolved ion content through the measuring of electrical resistance (Wetzl, 2001). Specific conductance values resemble the same trend as alkalinity values; July-August 2014 specific conductance minimum, maximum, and mean values were greater than historical values in the epilimnion and hypolimnion. The July-August 2014 mean hypolimnetic specific conductance value was approximately four times greater than the historical hypolimnetic mean value (Table 5). This comparison of historical and July-August 2014 data indicates increases in post-drawdown alkalinity and specific conductance values, with large increases in the hypolimnion due to thermal stratification. The increase in specific conductance values compared to historical data suggests an increase of dissolved ions after the complete drawdown.

The July-August 2014 mean Secchi depth value of 5.2 meters indicates that the water clarity within Griffy Lake has increased in comparison to pre-drawdown sampling events, which had a mean value of 3.8 meters (Table 5).

\section{Comparison with Other Indiana Lakes}

Table 6 gives values of water quality parameters determined for 355 Indiana lakes during July-August 1998-2010 by the Indiana Clean Lakes Program. This table can be used to compare mean values determined for Griffy Lake with other Indiana lakes. For all variables except nitrate and TKN, Griffy Lake mean values were greater than the median values for the 355 lake data set, indicating that Griffy is more productive than the majority of Indiana lakes. Additionally, the mean Secchi disk value indicates greater water clarity than the majority of Indiana lakes, supporting the fact that Griffy is a plant dominated lake.

\section{CONCLUSION}

The data presented indicates that post-drawdown, hypolimnetic nutrient concentrations, except nitrate, increased above pre-drawdown values. These data suggests that reservoirs in temperate climates experiencing a complete drawdown over an extended period (at least 2 years) will accumulate nutrients, with the exception of nitrate due to its oxidation state, in the hypolimnion during summer thermal stratification. This accumulation of nutrients may be the result of oxidized soils as well as the establishment of quickly colonizing terrestrial plants on the lakebed during the drawdown period. More long-term data is needed to understand how nutrient concentrations will change and be redistributed within the lake over time. Additionally, more research is necessary to understand how these changes in nutrient concentrations, as well as other abiotic variables, affect biotic components within the lake, such as algae, macrophytes, zooplankton, fish, and ecosystem processes.

\section{ACKNOWLED GMENTS AND CORRESPONDENCE}

The author would like to thank Melissa Clark for providing feedback on prior drafts of the manuscript. Additionally, thank you to the Clark Limnology Laboratory for funding, and Lauren Swierk and Jon Kruse for assisting in data collection.

All correspondence concerning this article should be addressed to Gregory P. Welage at gpwelage@gmail.com

\section{REFERENCES}

De Groot, C. J., \& Van Wijck, C. (1993). The impact of desiccation of a freshwater marsh (Garcines Nord, Camargue, France) on sediment-water-vegetation interactions. Hydrobiologia, 252(1), 83-94. doi: 10.1007/BF00000130

Holdren, C., Jones, W., \& Taggart, J. (2001). Managing lakes and reservoirs. North American Lake Management Society and the Terrene Institute, in coop. with Office of Water, Assessment and Watershed Protection Division. Madison, WI: U.S. Environmental Protection Agency

James, W.F., Barko, J.W., Eakin, H.L., \& Helsel, D.R. (2001). Changes in sediment characteristics following drawdown of Big Muskego Lake, Wisconsin. Archiv für Hydrobiologie, 151(3), 459-474. doi:

Klotz, R.L., \& Linn, S.A. (2001). Influence of factors associated with water level drawdown on phosphorus release from sediments. Lake and Reservoir Management, 17(1), 48-54. doi: 10.1080/07438140109353972

Peel, S. (2008). Griffy Lake Nature Preserve master plan. JF New. Walkerton, IN, p. 1.

Rice, E.W., Baird, R.B., Eaton, A.D., \& Clesceri, L.S. (Eds.). (2005). Standard methods for examination of water and wastewater. Washington, D.C.: American Public Health Association.

Wetzl, R.G. (2001). Limnology: Lake and river ecosystems. San Diego, CA: Academic Press. 


\section{INDIANA UNIVERSITY JOURNAL OF UNDERGRADUATE RESEARCH}

NATURAL SCIENCES

\section{APPENDIX: FIGURES}

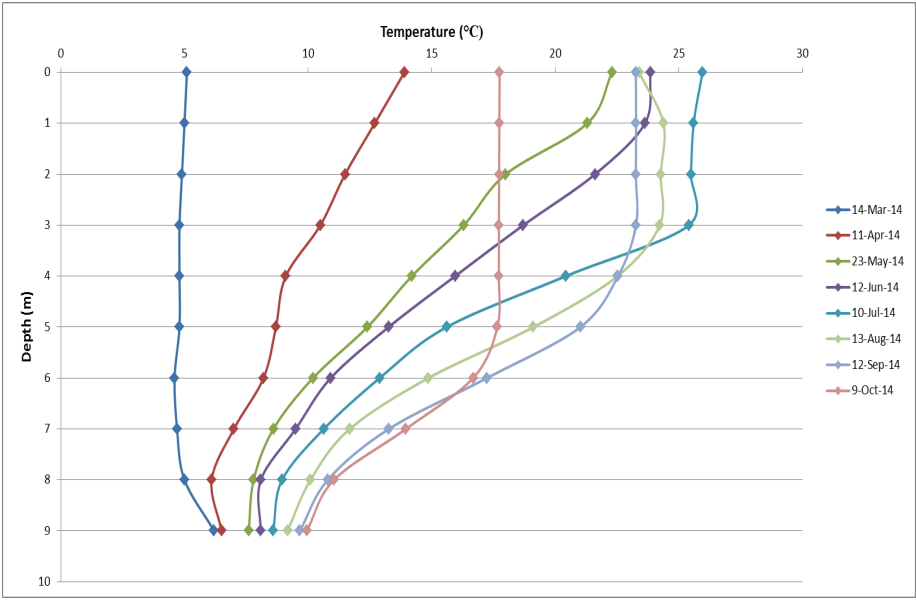

Figure 1: Temperature Profile for Griffy Lake from March to October 2014

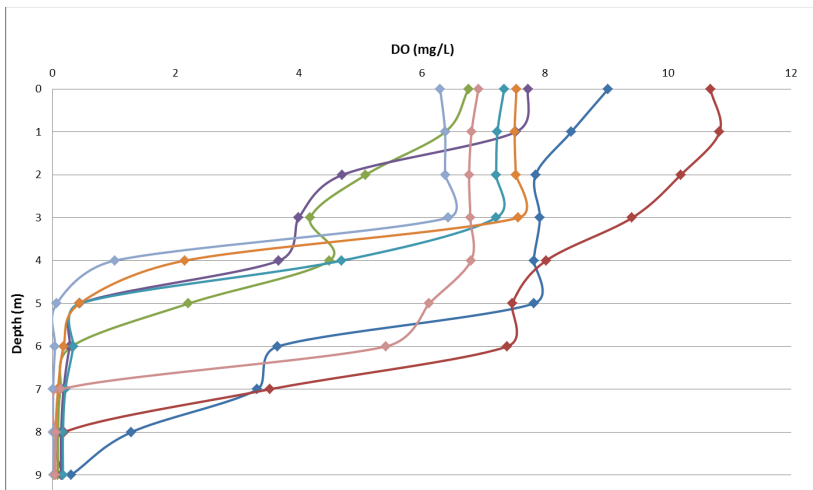

$\rightarrow$ 14Mar-14 $\rightarrow$ 11-Apr-14 $\rightarrow-23-$ May-14 $\rightarrow$ 12-Jun-14 $\rightarrow-10-$ Jul-14 $\rightarrow-13$-Aug-14 $\rightarrow-9.0 \mathrm{ct}-14$

Figure 2: Dissolved oxygen profile for Griffy Lake from March to October 2014

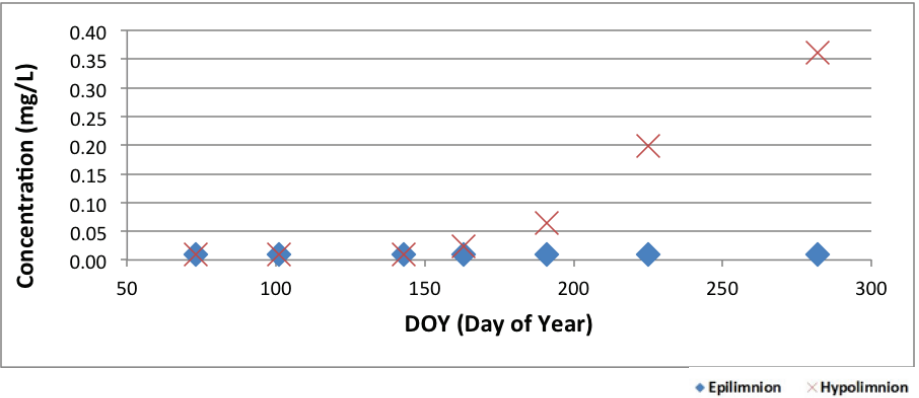

Figure 3: Time series of SRP concentrations from Griffy Lake from March to October 2014

Note. Samples were collected during the second week of each month.

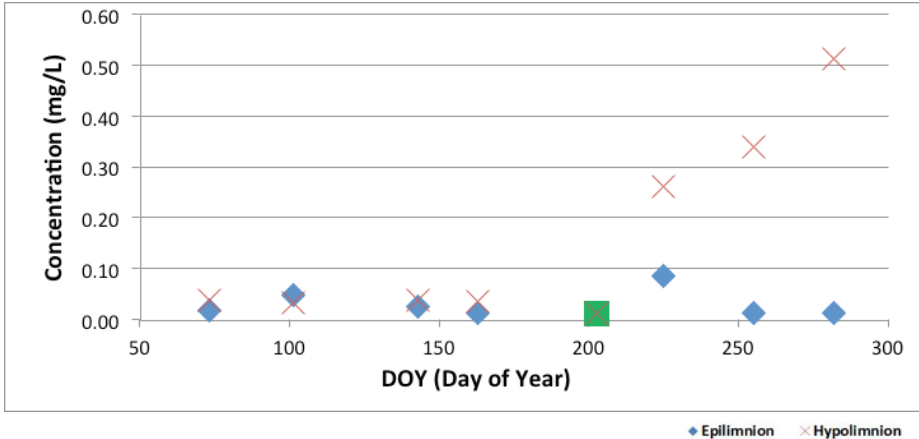

Figure 4: Time series of TP concentrations from Griffy Lake from March to October 2014

Note. Samples were collected during the second week of each month. Green data point represents supplemental data from sampling events taken by Parks and Recreation employees

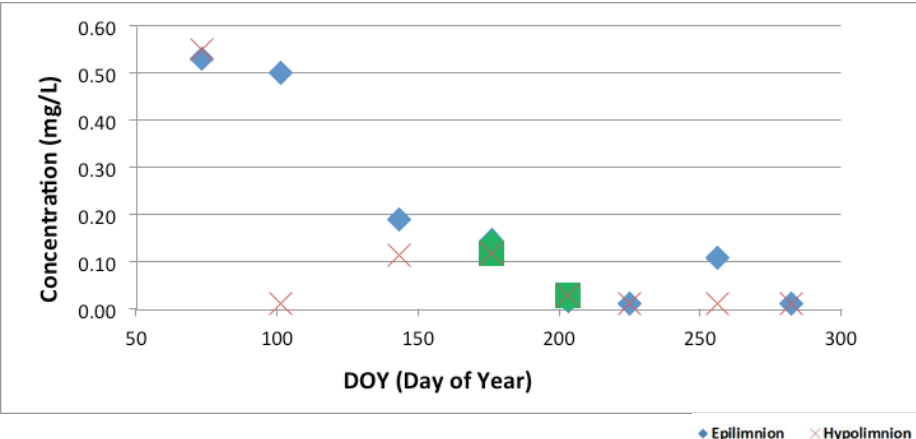

Figure 5: Time series of $\mathrm{NO}^{-}-\mathrm{N}$ concentrations from Griffy Lake from March to October 2014

Note. Samples were collected during the second week of each month. Green data points represent supplemental data from sampling events taken by Parks and Recreation employees

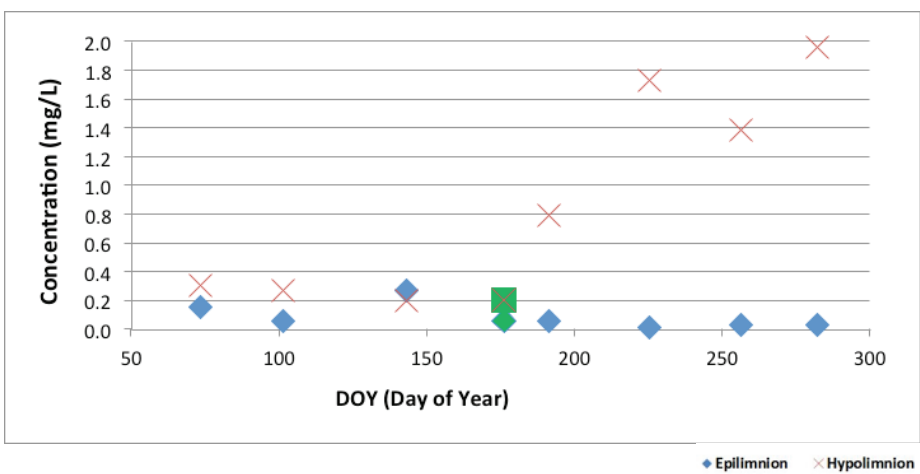

Figure 6: Time series of $\mathrm{NH}_{4}^{+}-\mathrm{N}$ concentrations from Griffy Lake from March to October 2014

Note. Samples were collected during the second week of each month. Green data points represent supplemental data from sampling events taken by Parks and Recreation employees 


\section{INDIANA UNIVERSITY JOURNAL OF UNDERGRADUATE RESEARCH}

\section{NATURAL SCIENCES}

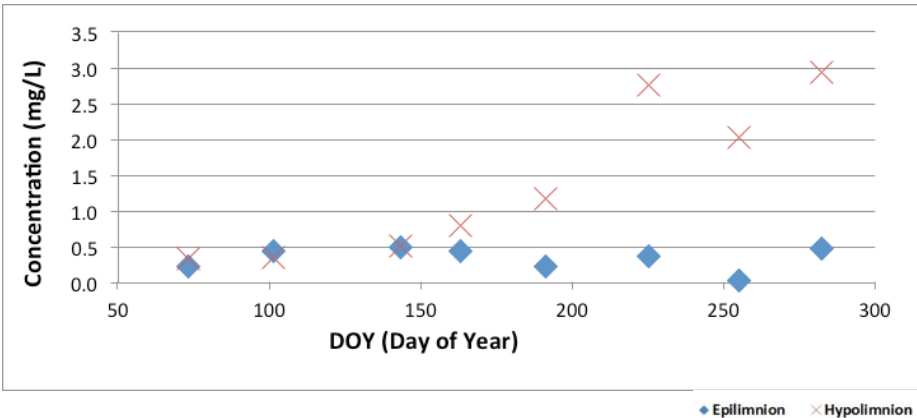

Figure 7: Time series of TKN concentrations from Griffy Lake from March to October 2014

Note. Samples were collected during the second week of each month.

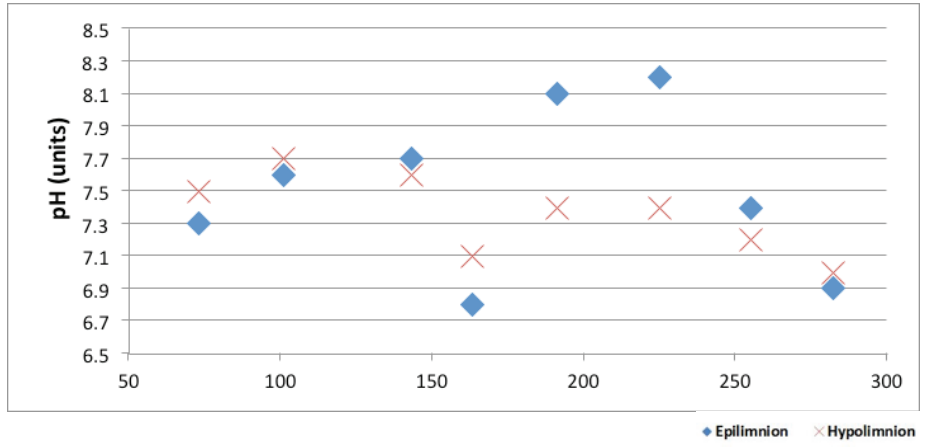

Figure 8: Time series of $\mathrm{pH}$ values from Griffy Lake from March to October 2014

Note. Samples were collected during the second week of each month.

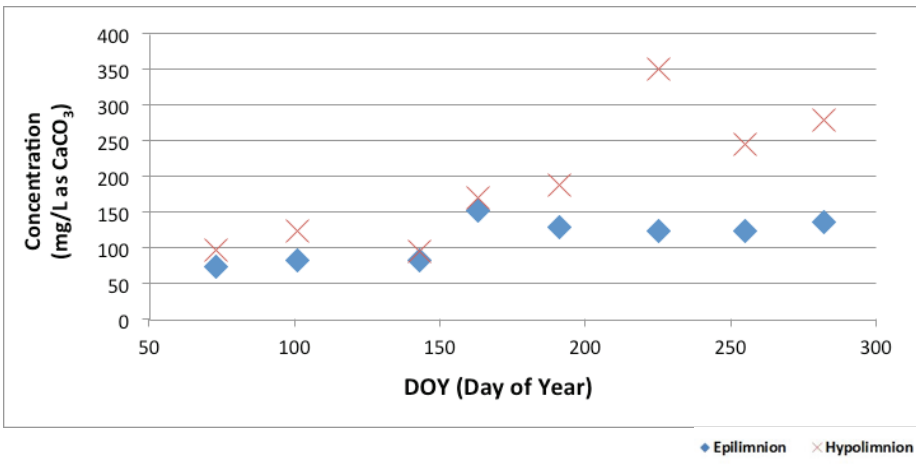

Figure 9: Time series of alkalinity concentrations (as $\left.\mathrm{CaCO}_{3}\right)$ from Griffy Lake from March to October 2014.

Note. Samples were collected during the second week of each month.

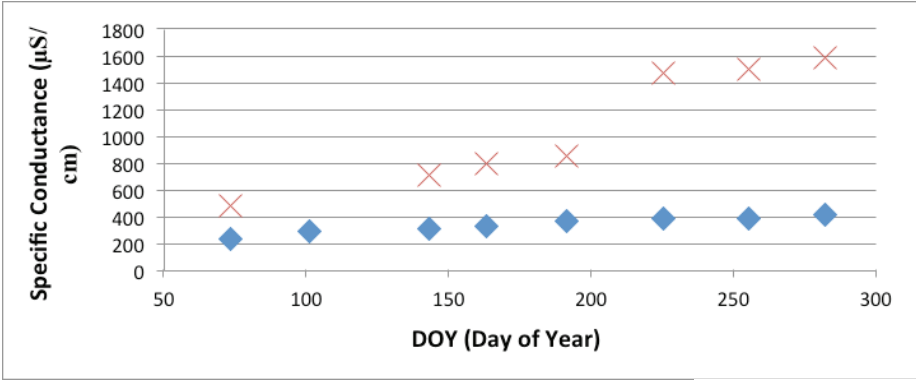

Figure 10: Time series of specific conductance from Griffy Lake from March to October 2014

Note. Samples were collected during the second week of each month. The April hypolimnetic value was not obtained due to instrument error

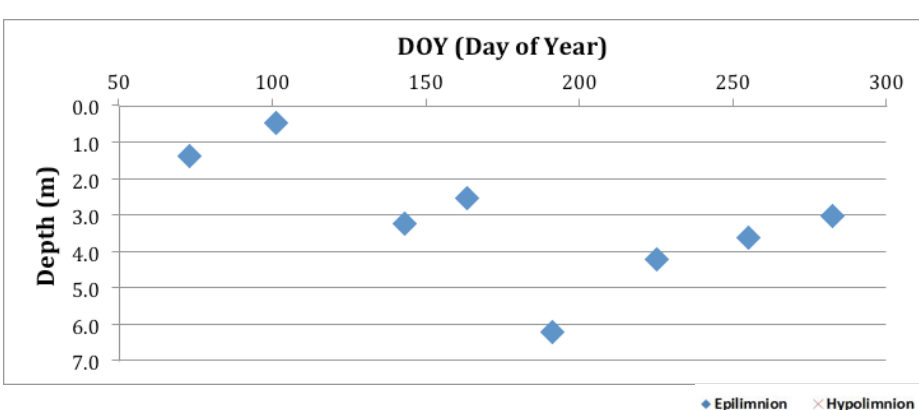

Figure 11: Time series of Secchi depth from Griffy Lake from March to October 2014

Note. Samples were collected during the second week of each month.

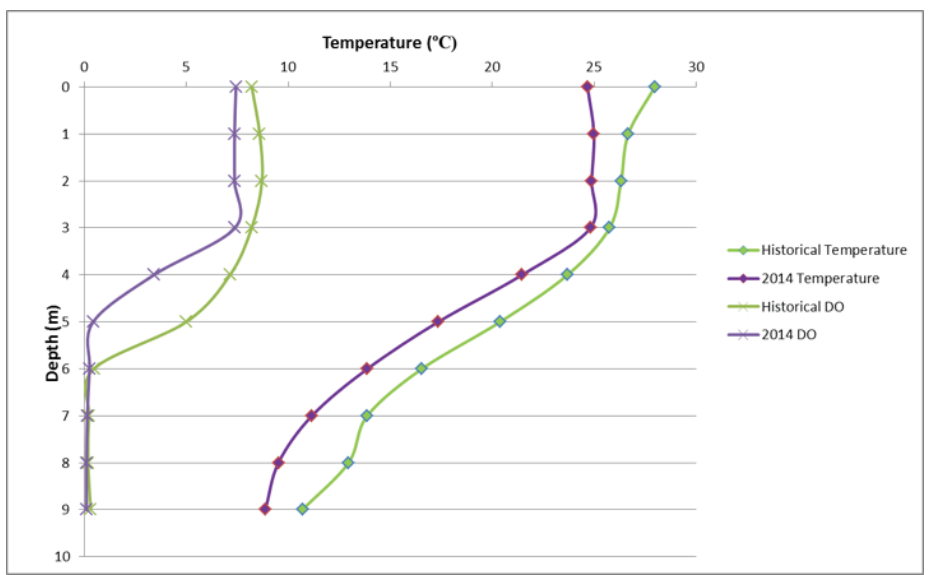

Figure 12: Temperature profiles of averaged historical data (July 1990, July 1997, August 2001, July 2009, and August 2001) and averaged measurements from two sampling events in July and August 2014 at Griffy Lake 


\section{INDIANA UNIVERSITY JOURNAL OF UNDERGRADUATE RESEARCH}

\section{NATURAI SCIFNCFS}

\section{APPENDIX: TABLES}

Table 1: Mean, maximum, detection limit, and standard deviation for SRP and TP concentrations from Griffy Lake during monthly sampling events from March to October in 2014.

\begin{tabular}{lllll}
\hline & & $\begin{array}{l}\text { SRP } \\
\mathbf{m g} / \mathbf{L}\end{array}$ & $\begin{array}{c}\text { TP } \\
\mathbf{m g} / \mathbf{L}\end{array}$ \\
\hline mean & Epilimnion & Hypolimnion & Epilimnion & Hypolimnion \\
maximum & $0.010^{*}$ & 0.097 & 0.030 & 0.160 \\
minimum & $0.010^{*}$ & 0.361 & 0.088 & 0.515 \\
std dev. & $0.010^{*}$ & $0.010^{*}$ & $0.010^{*}$ & $0.010^{*}$ \\
& 0.000 & 0.135 & 0.027 & 0.189 \\
\hline
\end{tabular}

Table 2: Mean, maximum, minimum, and standard deviation for $\mathrm{NO}_{3}-\mathrm{N}, \mathrm{NH}_{4}^{+}-\mathrm{N}$, and TKN concentrations from Griffy Lake during monthly sampling events from March to October in 2014 $\begin{array}{ccc}\mathrm{NO}_{3}^{-}-\mathrm{N} & \mathrm{NH}_{4}{ }^{-}-\mathrm{N} & \mathrm{TKN} \\ \mathrm{mg} / \mathrm{L} & \mathrm{mg} / \mathrm{L} & \mathrm{mg} / \mathrm{L}\end{array}$

\begin{tabular}{lllllll} 
& \multicolumn{2}{c}{$\mathrm{mg} / \mathrm{L}$} & \multicolumn{2}{c}{$\mathrm{mg} / \mathrm{L}$} & \multicolumn{2}{c}{$\mathrm{mg} / \mathrm{L}$} \\
\hline & Epilimnion & Hypolimnion & Epilimnion & Hypolimnion & Epilimnion & Hypolimnion \\
mean & 0.191 & 0.108 & 0.088 & 0.858 & 0.337 & 1.349 \\
maximum & 0.532 & 0.551 & 0.274 & 1.966 & 0.469 & 2.937 \\
minimum & $0.013^{*}$ & $0.013^{*}$ & $0.018^{*}$ & 0.202 & $0.230^{*}$ & 0.330 \\
std dev. & 0.212 & 0.185 & 0.086 & 0.735 & 0.186 & 1.085 \\
\hline
\end{tabular}

*Method detection limit

Table 3: Mean, maximum, minimum, and standard deviation for pH, alkalinity, and specific conductance values from Griffy Lake during monthly sampling events from March to October in 2014.

\begin{tabular}{|c|c|c|c|c|c|c|}
\hline & \multicolumn{2}{|c|}{$\begin{array}{l}\mathrm{pH} \\
\text { units }\end{array}$} & \multicolumn{2}{|c|}{$\begin{array}{c}\text { Alkalinity } \\
\mathrm{mg} / \mathrm{L}\left(\text { as } \mathrm{CaCO}_{3}\right)\end{array}$} & \multicolumn{2}{|c|}{$\begin{array}{c}\mathrm{SpC} \\
\mu \mathrm{S} / \mathrm{cm}\end{array}$} \\
\hline & Epilimnion & Hypolimnion & Epilimnion & Hypolimnion & Epilimnion & Hypolimnion \\
\hline mean & 7.5 & 7.4 & 114 & 194 & 345 & 1059 \\
\hline maximum & 8.1 & 7.7 & 152 & 351 & 422 & 1592 \\
\hline minimum & 6.8 & 7.0 & 74 & 97 & 241 & 481 \\
\hline std dev. & 0.5 & 0.2 & 29 & 92 & 59 & 450 \\
\hline
\end{tabular}

Table 4: Mean, maximum, minimum, and standard deviations of averaged nutrient concentrations from historical and July-August 2014 datasets for Griffy Lake.

\begin{tabular}{|c|c|c|c|c|}
\hline & \multicolumn{2}{|c|}{ Historical } & \multicolumn{2}{|c|}{ July-August 2014} \\
\hline & Epilimnion & Hypolimnion & Epilimnion & Hypolimnion \\
\hline \multicolumn{5}{|l|}{ SRP (mg/L) } \\
\hline mean & $0.010^{*}$ & 0.015 & $0.010 *$ & 0.132 \\
\hline maximum & $0.010^{*}$ & 0.028 & 0.010 * & 0.198 \\
\hline minimum & $0.010^{*}$ & $0.010^{*}$ & $0.010 *$ & 0.065 \\
\hline std dev & 0.000 & 0.008 & 0.000 & 0.094 \\
\hline \multicolumn{5}{|l|}{$\mathrm{TP}(\mathrm{mg} / \mathrm{L})$} \\
\hline mean & 0.023 & 0.050 & 0.049 & 0.138 \\
\hline maximum & 0.060 & 0.065 & 0.088 & 0.264 \\
\hline minimum & 0.013 & 0.018 & $0.010^{*}$ & 0.012 \\
\hline std dev & 0.021 & 0.020 & 0.055 & 0.178 \\
\hline \multicolumn{5}{|c|}{$\mathrm{NO}_{3}^{-}-\mathrm{N}(\mathrm{mg} / \mathrm{L})$} \\
\hline mean & 0.104 & 0.055 & 0.016 & 0.021 \\
\hline maximum & 0.221 & 0.119 & 0.019 & $0.013^{*}$ \\
\hline minimum & $0.013^{*}$ & $0.013^{*}$ & 0.028 & $0.013^{*}$ \\
\hline std dev & 0.091 & 0.052 & 0.004 & 0.011 \\
\hline \multicolumn{5}{|c|}{$\mathrm{NH}_{4}{ }^{+}-\mathrm{N}(\mathrm{mg} / \mathrm{L})$} \\
\hline mean & 0.049 & 0.527 & 0.039 & 1.264 \\
\hline maximum & 0.158 & 1.634 & 0.059 & 1.731 \\
\hline minimum & $0.018^{*}$ & 0.038 & $0.018 *$ & 0.796 \\
\hline std dev & 0.061 & 0.650 & 0.029 & 0.661 \\
\hline \multicolumn{5}{|l|}{ TKN (mg/L) } \\
\hline mean & 0.536 & 1.167 & 0.300 & 1.961 \\
\hline maximum & 1.185 & 2.466 & 0.366 & 2.756 \\
\hline minimum & 0.329 & 0.518 & 0.234 & 1.166 \\
\hline std dev & 0.365 & 0.837 & 0.093 & 1.124 \\
\hline
\end{tabular}

*Method detection limit 


\section{INDIANA UNIVERSITY JOURNAL OF UNDERGRADUATE RESEARCH}

NATURAL SCIENCES

Table 5: Mean, maximum, minimum, and standard deviations of the averaged concentrations from historical and July-August 2014 datasets for Griffy Lake.

\begin{tabular}{|c|c|c|c|c|}
\hline & \multicolumn{2}{|c|}{ Historical } & \multicolumn{2}{|c|}{ July-August 2014} \\
\hline & Epilimnion & Hypolimnion & Epilimnion & Hypolimnion \\
\hline \multicolumn{5}{|l|}{ pH (units) } \\
\hline mean & 8.2 & 7.6 & 8.2 & 7.4 \\
\hline maximum & 8.3 & 8.7 & 8.2 & 7.4 \\
\hline minimum & 7.4 & 7.2 & 8.1 & 7.4 \\
\hline std dev & 0.5 & 0.6 & 0.1 & 0.0 \\
\hline \multicolumn{5}{|c|}{$\begin{array}{l}\text { Alkalinity } \\
\left(\mathrm{mg} / \mathrm{L} \text { as } \mathrm{CaCO}_{3}\right)\end{array}$} \\
\hline mean & 96 & 140 & 128 & 270 \\
\hline maximum & 106 & 183 & 130 & 351 \\
\hline minimum & 81 & 116 & 125 & 188 \\
\hline std dev & 10 & 26 & 4 & 115 \\
\hline \multicolumn{5}{|l|}{$\mathrm{SpC}(\mu \mathrm{S} / \mathrm{cm})$} \\
\hline mean & 248 & 265 & 379 & 1164 \\
\hline maximum & 260 & 281 & 389 & 1473 \\
\hline minimum & 230 & 250 & 368 & 854 \\
\hline std dev & 11 & 15 & 15 & 438 \\
\hline \multicolumn{5}{|c|}{ Secchi Disk (m) } \\
\hline mean & \multicolumn{2}{|r|}{3.8} & \multicolumn{2}{|c|}{5.2} \\
\hline maximum & \multicolumn{2}{|r|}{5.0} & \multicolumn{2}{|c|}{6.2} \\
\hline minimum & \multicolumn{2}{|r|}{2.5} & \multicolumn{2}{|c|}{4.2} \\
\hline std dev & \multicolumn{2}{|c|}{0.91} & \multicolumn{2}{|c|}{1.41} \\
\hline
\end{tabular}

Table 6: July-August Water Quality Characteristics of 355 Indiana Lakes

Note. Sampled From 1998 thru 2010 by the Indiana Clean Lakes Program compared to Griffy Lake. Means of epilimnion and hypolimnion samples from July and August sampling events were used for Griffy Lake values.

\begin{tabular}{|c|c|c|c|c|c|c|}
\hline & Secchi & $\mathrm{NO}_{3}{ }^{-}-\mathrm{N}$ & $\mathrm{NH}_{4}{ }^{+}-\mathrm{N}$ & TKN & TP & SRP \\
\hline & Disk (m) & $(\mathrm{mg} / \mathrm{L})$ & $(\mathrm{mg} / \mathrm{L})$ & $(\mathrm{mg} / \mathrm{L})$ & $(\mathrm{mg} / \mathrm{L})$ & $(\mathrm{mg} / \mathrm{L})$ \\
\hline Median & 1.7 & 0.046 & 0.455 & 1.199 & 0.082 & 0.028 \\
\hline Maximum & 16 & 16.68 & 16.35 & 20.87 & 4.894 & 1.427 \\
\hline Minimum & 0.1 & $0.013 *$ & $0.018 *$ & $0.230 *$ & $0.010 *$ & $0.010 *$ \\
\hline \multicolumn{7}{|l|}{ Values for } \\
\hline $\begin{array}{l}\text { Griffy L. } \\
(8 / 13 / 2014)\end{array}$ & 5.2 & 0.019 & 0.652 & 1.131 & 0.094 & 0.071 \\
\hline
\end{tabular}

*Method detection limit 